\title{
The Effect of Content Marketing on Decision Making of Graduate School of Business Administration in
} Thailand

\author{
Thanisorn Rojanadilok, Viroj Daraviroj \\ Huachiew Chalermprakiet University, Thailand \\ daradaraviroj28@gmail.com
}

\begin{abstract}
This study was an investigation of undergraduate student use content marketing to decision to study in the graduate school of business administration in Chonburi, Thailand. The graduate education prepares students for research in professional program. In 2019, there is a lot of connection among people through the use of information and can leverage social media marketing to enhance their programs. The performance of the workplace offers the persons who graduate in graduate education level. The educators need content marketing to decision making to study in graduate school of business administration in Thailand. This study was qualitative research by In-depth interview of 30 bachelor degree's people which three people from each district in Chonburi, Thailand. The research has significant in the website's content, and facebook's content of graduate school of business administration. The factors influence to apply to study in master and doctoral degree were the graduation programs, cost of attendance, graduation degree, location of the campus, university reputation, alumni, and current students opinion to graduate school.
\end{abstract}

Keywords: Content marketing, decision making, school of business administration, Thailand

\section{Introduction}

The people want to study master or doctoral in business administration faculty because they will professional in careers with business degree, progress in job position, get highest paying jobs, has performance to negotiate your salary, and success in your entrepreneurial business. This research wants to describe content marketing of graduate school of business administration for undergraduate students to decide to obtain graduate education in Thailand. Content marketing used to establish expertise, added value to blogging, Ebook, online videos, press release, podcasts, Emails, Webinars, infographics and cartoon. Content marketing is a type of marketing that purpose directly, and indirectly promoting a business on digital marketing (online marketing) and traditional (offline marketing). The benefits of content marketing on SEO (Search Engine Optimization) improve customer services such as tutorials, FAQs, and community updates. The content in the website of graduate school must include the details of why choose our university for your graduate studies, requirement, deadlines admission, financial aid, funding, tuition, fee, preparing to graduate, forms ,related policies, meeting, faculty membership, supervising, links, and program.

Research Objective: To describe content marketing of graduate school of business administration for undergraduate students to d0ecide to obtain graduate education in Thailand.

\section{Review of Literature}

Content Marketing is a strategic marketing approach focused on creating, distributing valuable, relevant, consistent content to attract ,maintain a clearly defined audience, and ultimately to result in a profitable action of the client for business (Content Marketing Institute, 2019). Opreana \& Vinerean (2015) told that online business can no longer rely on traditional marketing tactics, campaigns to attract, retain, and expand consumers because there is a transformation in how people interact with brands, and companies. Traditional marketing is no longer an available option because it focused on pushing a message out. Online business framework focused on attracting valuable consumers (potential, existing) that choose to interact with a particular company that provides them with something useful. Kreeson et al. (2014) study that postgraduate students utilize the socialization, externalization modes of knowledge conversation comprehensively; internalization plays a significant role in their knowledge creation, and transfer activities. Cenek et al. (2016) researched that the main marketing tools used on Facebook, e.g. paid target banner ad on Facebook, the extent of paid facebook. The content a target, and segment the posts to a specific group of online users. The content of your posts news on your university, open a discussion, and public inquiry, posts about new 
information from your websites. Zeynep \& Keskin (2014) told that mobile application name is "Marketing Genius". The rich content in application preference on visual learning style, auditory learning style.

If the students do not want or have a chance to read the text, he/she could listen to the audio recording. Byun et al. (2018) seen in the study that networking has proven to be a key role for small business success. The graduate students view networking skill as an important factor in their success as an entrepreneur and show that it is necessary to activate an educational program to support it and to emphasize it as a key factor in entrepreneurial programs. In addition, entrepreneurs have generally emphasized the usefulness of networking the creation of social networking websites can be effective in building and maintaining a relationship with alumni and business partners. Mugahed et al. (2016) study social media has been always described as the channel through which knowledge is transmitted between community and learners. The content a target, and segment the posts to a specific group of online users. The social media has been utilized by colleges in a way to encourage collaborative learning and social interaction. Luminita et al. (2016) study that the skill and knowledge that employers expect from graduates to have communication skill that allows them to communicate non-technical information to technical people. The commitment to continue their professional development, and help others to imparts their knowledge.

\section{Methodology of Research}

The study employed descriptive qualitative research. The sample sizes are thirty undergraduate degree's people. The sample size includes 10 districts, and three people from each district (Muang, Banglamung, Sathaheap, Nongyai, Panatnikom, Banbung, Panthong, Baothong, Kaosrichang, and Sriracha) in Chonburi, Thailand. The qualitative research using In-depth interview guideline to collect the data the instruments to obtain the data used interview guideline.

- The Demographic data are age of participants, occupation, and income?

- How often do you use social media per day?

- How often do you use social media to find out content to decision making in the graduate school of business?

- What is the favorite search engine to find the content to decision making in graduate school of business?

- What is the important content to decision making in the graduate school of business?

Data Analysis: qualitative research using content analysis to describe the data.

Propose of Hypothesis: HO: There is a significant effect of content marketing on decision making in graduate school of business. The aim of the research is to describe content marketing of graduate business curriculum for undergraduate students to decide to obtaining graduate education.

\section{Results of Research}

General Information of Participants: Interviewees age between 21-46 years old who want to apply graduate school of business, income between 10,000-50,000 baht (315.93-1,579.65 USD) per month, and all of interviewees are employees in company.

Table 1: Descriptive Information of Participants on Social Media

\begin{tabular}{llll}
\hline Measure & \multicolumn{1}{c}{ Value } & Frequency & Percentage \\
\hline Social media used & 1-2 times & 3 & 10.0 \\
per day & $3-4$ times & 0 & 0.0 \\
& 5-6 times & 0 & 0.0 \\
& More than 6 times & 27 & 90.0 \\
& Total & 30 & 100.0
\end{tabular}




\begin{tabular}{lllc} 
Social media used & $1-2$ times & 9 & 30.0 \\
to find information & $3-4$ times & 15 & 50.0 \\
of graduate school & $5-6$ times & 3 & 10.0 \\
of business & More than 6 times & 3 & 10.0 \\
& & 30 & 100.0 \\
\hline
\end{tabular}

Table 2: Sample's Perspective to Content of Graduate School of Business on Social Media

\begin{tabular}{ll}
\hline Content items & Social Usage (person) \\
\hline Facebook's content & 18 \\
Instagram's content & 0 \\
Youtube's contents(Video) & 6 \\
Website & 30 \\
@line,and etc & 3 \\
\hline
\end{tabular}

The content marketing affecting the decision to study in graduate school of business administration are a website ( $100 \%$ of sample usage) and Facebook fan page ( $40 \%$ of sample usage). The seven significant content items which affecting decision to study in graduate school of business are graduate program (100\%of sample), cost of attendance ( $100 \%$ of sample), campus location ( $80 \%$ of sample), university reputation $(100 \%$ of sample), graduation degree ( $100 \%$ of sample), alumni of university ( $70 \%$ of sample) connection to current students $(70 \%$ of sample). The twelve content items not significantly affecting the decision to study in graduate school of business administration are library resources (0\% of sample), get help from university (10\% of sample) the researcher $(0 \%$ of sample), staff $(0 \%$ of sample), qualification of students $(10 \%$ of sample), contact school (30\% of sample), application fee ( $0 \%$ of sample), what is last date to apply ( $0 \%$ of sample), online application form ( $0 \%$ of sample), demonstration of English proficiency (30\% of sample) teaching, research assistantship ( $0 \%$ of sample), and technology resource ( $0 \%$ of sample).

\section{Conclusion and Discussion}

The website is engagement tools to answer prospective graduate students question, using facebook lives for student recruitment, long term broadcast lecture, conference can successful in attracting undergraduate student to engage in graduate business school. Regularly post content on website, facebook about 5-10 times per week. The good content is video, drawing picture, infographic, and youtube. The Instagram,@line, blog, the mobile application is no sample usage because of students focus on website and facebook. The reasons graduate school should include video in a content marketing plan to reach the target audience are stronger student attention, higher engagement greater optimization opportunities higher retention rates. Policy guideline in the website of graduate schools of business should have strong information about the content items affecting the decision making in the graduate school of business administration in Thailand.

- Graduate programs the graduate school of business should clear the programs, curriculum overview kind of master or doctoral degree. Specific field in master or doctoral degree professional skill from degree to earn salary higher jobs position and the benefit after earning the master or doctoral degree.

- Cost of attendance and payment schedule the student's concern about direct and indirect cost. The graduate school of business should clear the cost as following tuition, application fee, registration fee, discount, scholarship, technology fee, loan fees, financial aid, and health insurance. Living cost such as personal expenses, transportation, housing, books, equipment's overdue payments, and late enrollment methods of payment.

- Campus location has the detail of address, postal address, telephone, and map.

- University reputation is the most important factor influencing to apply in university. The university reputation helps to improve credit, experience, trust and outcome that student is hoping.

- Graduation degree, Master and doctoral degree can significantly increase your potential, entry-level position, and get a promotion to a higher position. 
- Alumni of the university, alumni relationship help to promote direct and indirect information of university.

- Connection to current students, the current student, can share expertise, and help to recruit new students.

The website of graduate schools of business should educate, and prepare students with the knowledge to provide leadership to organizations. The students can able to solve the complex problems, able to apply decision-making techniques, analyze the problem that occurs in business. The students will evaluate the strategic formulation plan to integrate knowledge of business in a global environment.

Discussion: Other content marketing affecting the decision to study in graduate school of business administration are open house of graduate university, and introduce graduate business curriculum of university, Booth exhibition, event for introduce course, curriculum of graduate business curriculum, trial class at your business university, online business course for working people by using Skype program in PC computer, tablet, smartphone, Artificial Intelligence can develop quality contents, remarketing can give universities access and attractive the target students. The graduation study can enhance career prospects, increase your knowledge in areas of digital marketing, strategic marketing, marketing research, customer relationship management, digital social media for increase your potential for a job position, and get a lot of job opportunities in graduate study.

Implication of Research: Students have a different reason for studying a master or doctoral degree the most reason for applying to the graduate school of business. It is a great way to advance the position to a manager or higher position. The degree can improve the salary at a new job or the same company. The master and doctoral degree can make the resume stand out can make it easier to get the job his/her want. Students update his/her knowledge and field experience. The graduate courses obtain a professional qualification. Students needed to pursue his/her chosen career.

\section{References}

Byun, C., Sung, C., Park, J. \& Choi, D. (2018). A study on the Effectiveness of Entrepreneurship Education Programs in Higher Education Institutions: A Case Study of Korean Graduate Programs. Journal Open Innovation: Technology, Market, and Complexity, 4(26), 1-14.

Cenek, J., Smolik, J. \& Svatosova, V. (2016). Marketing on social network: content analysis of Facebook profiles of selected CZECH E-Shops. Trends economics and management, 26(2), 9-20.

Content Marketing Institute. (2019). What is Content Marketing?

Kreeson, N., Krishna, G. \& Karunagaran, N. (2014). Knowledge creation and transfer among post-graduate students. South African Journal of Information Management, 16(1), 1-8.

Kumar, A., Bezawada, R., Rishika, R., Janakiraman, R. \& Kannan, P. (2016). From Social to Sale: The Effects of Firm-Generated Content in Social Media on Customer Behavior. Journal of Marketing, 80(1), 7-25.

Lamberton, C. \& Stephen, A. (2016). A Thematic Exploration of Digital, Social Media, and Mobile Marketing: Research Evolution from 2000 to 2015 and an Agenda for Future Inquiry. Journal of Marketing, 80, 146-172.

Lieb, R. \& Szymanski, J. (2017). Content, the Atomic Particle of Marketing: The Definitive Guide to Content Marketing Strategy (1 ${ }^{\text {st }}$ ed.). New York: Kogan Page.

Luminita, H., Vasile, D. \& Doina, F. (2016). Improving graduates' employability in it field. The case study of accounting and information systems study program. Review of Economic Business Studies, 8(2), 135148.

Mugahed, W., Rahm, A. \& Zeki, A. (2016). A model of using social media for collaborative learning to enhance learners' performance on learning. Journal of King Saud University-Computer and Information Sciences, 526-535.

Opreana, A. \& Vinerean, S. (2015). A New Development in Online Marketing: Introducing Digital Inbound Marketing. Expert, Journal of Marketing, 3(1), 29-34.

Zeynep, 0. \& Keskin, N. (2014). Students' preferences and opinions on design of a mobile marketing education application. Turkish Online Journal of Distance Education, 15(1), 189-205. 